\title{
KEBERSIHAN GIGI DAN MULUT TERHADAP TERJADINYA KARIES PADA ANAK SEKOLAH DASAR DI MAKASSAR
}

Pariati, Nur Aini Lanasari

STIKES Amanah Makassar

\begin{abstract}
ABSTRAK
Kebersihan gigi dan mulut adalah keadaan yang menunjukkan bahwa di dalam rongga mulut seseorang bebas dari kotoran, seperti plak dan calculus. Apabila kebersihan gigi dan mulut terabaikan akan terbentuk plak pada gigi geligi dan meluas keseluruh permukaan gigi. Apabila kebersihan gigi dan mulut terabaikan akan terbentuk plak pada gigi geligi dan meluas keseluruh permukaan gigi. Karies gigi pada anak usia sekolah dasar kebiasaan makan makanan kariogenik. Anak memasuki usia sekolah pada umumnya mempunyai resiko karies yang tinggi, karena pada usia ini anak-anak suka jajan sembarangan seperti makanan yang manis dan lengket.Anak usia sekolah adalah satu usia yang rentan terhadap penyakit gigi dan mulut karena umumnya pada usia tersebut masih mempunyai perilaku atau kebiassan diri yang kurang menunjang terhadap kesehatan gigi.(kariogenik).Kondisi mulut yang selalu basah, gelap, dan lembab sangat mendukung pertumbuhan dan perkembangbiakan bakteri yang membentuk plak. Karies gigi adalah sebuah penyakit infeksi yang merusak struktur jaringan keras gigi. penyakit ini ditandai dengan gigi berlubang. lubang gigi disebabkan oleh beberapa tipe dari bakteri penghasil asam yang dapat merusak karena reaksi fermentasi karbohidrat termasuk sukrosa,fruktosa,dan glukosa. Penelitian ini bertujuan untuk mengetahui kebersihan gigi dan mulut terhadap terjadinya karies pada anak usia sekolah dasar kelas IV di SD Negeri Minasa Upa Kel. Minasa Upa. Adapun sampel yang di ambil dengan menggunakan proposive sampling yaitu 54 anak dari populasi yang berjumlah 605 orang. Hasil penelitian menunjukkan bahwa Kebersihan Gigi dan mulut $(\mathrm{OHI}-\mathrm{S})$ berada pada kategori sedang dengan status karies (def-t) kategori sangat rendah dan status karies (DMF-T) kategori sedang.
\end{abstract}

Kata Kunci: Anak, Karies, Kebersihan

\section{PENDAHULUAN}

Kebersihan gigi dan mulut adalah keadaan yang menunjukkan bahwa di dalam rongga mulut seseorang bebas dari kotoran, seperti plak dan calculus. Apabila kebersihan gigi dan mulut terabaikan akan terbentuk plak pada gigi geligi dan meluas keseluruh permukaan gigi. Kondisi mulut yang selalu basah, gelap, dan lembab sangat mendukung pertumbuhan dan perkembangbiakan bakteri yang membentuk plak. Kesehatan merupakan bagian terpenting dalam kehidupan manusia, baik sehat secara jasmani dan rohani. Tidak terkecuali anak-anak, setiap orang tua menginginkan anaknya bisa tumbuh dan berkembang secara optimal (Be, 2017).

Karies gigi adalah sebuah penyakit infeksi yang merusak struktur jaringan keras gigi. penyakit ini ditandai dengan gigi berlubang. lubang gigi disebabkan oleh beberapa tipe dari bakteri penghasil asam yang dapat merusak karena reaksi fermentasi karbohidrat termasuk sukrosa,fruktosa, dan glukosa (Be, 2017).
Karies gigi pada anak usia sekolah dasar sangat dipengaruhi dari kebiasaan makan makanan kariogenik. Anak memasuki usia sekolah pada umumnya mempunyai resiko karies yang tinggi, karena pada usia ini anak-anak suka jajan sembarangan seperti makanan yang manis dan lengket.Anak usia sekolah adalah satu usia yang rentan terhadap penyakit gigi dan mulut karena umumnya pada usia tersebut masih mempunyai perilaku atau kebiassan diri yang kurang menunjang terhadap kesehatan gigi (kariogenik) (Worotijan dkk, 2016). peneliti saat melakukan penelitian.

\section{Kebersihan Gigi dan Mulut}

Kebersihan gigi dan mulut adalah suatu keadaan yang menunjukan bahwa di dalam mulut seseorang bebas dari kotoran seperti debris, plak dan karang gigi.plak akan selalu terbentuk pada gigi geligi dan meluas keseluruh permukaan gigi apabila seseorang mengabaikan kebersihan gigi dan mulut (Rusmawati, 2017). 
Putri, Herijulianti, dan Nurjannah (2016), faktor-faktor yang mempengaruhi kebersihan gigi dan mulut yaitu:

a. Menyikat gigi

b. Frekuensi menyikat gigi

c. Cara menyikat Gigi

d. Jenis Makanan

Menurut Putri, Herijulianti, dan Nurjanah (2010), mengatakan bahwa menyikat gigi adalah tindakan membersihkan gigi dan mulut dari sisa makanan dan debris yang bertujuan untuk mencegah terjadinya penyakit pada jaringan keras maupun jaringan lunak. Manson (dalam Putri, Herijulianti, dan Nurjanah, 2016), menyikat gigi sebaiknya dua kali sehari yaitu pagi setelah makan pagi dan malam sebelum tidur.

Tarigan, 2016 fungsi mekanis dari makanan yang dimakan berpengaruh dalam menjaga kebersihan gigi dan mulut, di antaranya:

a. Makanan yang bersifat membersihkan gigi, yaitu makanan yang berserat dan berair seperti : buah-buahan dan sayur-sayuran.

b. Sebaliknya makanan yang dapat merusak gigi yaitu makanan yang manis dan mudah melekat pada gigi seperti: coklat, permen, biskuit, dan lain-lain.

\section{Cara memelihara kebersihan gigi dan mulut}

Cara memelihara kebersihan gigi dan mulut yaitu dengan kontrol plak dan scalling

a. Kontrol plak

Kontrol plak adalah pengurangan plak mikroba dan pencegahan akumulasi plak pada gigi dan permukaan gusi yang berdekatan, memperlambat pembentukan karang gigi. Kontrol plak merupakan cara yang efektif dalam merawat dan mencegah gingivitis serta merupakan bagian yang sangat penting dalam urutan perawatan dan pencegahan penyakit rongga mulut (Fauzan, 2016).

b. Scaling

Scaling adalah suatu proses membuang plak dan calculus dari permukaan gigi. Tujuan utama dari scaling adalah mengembalikan kesehatan gusi dengan cara membuang semua elemen yang menyebabkan radang gusi, (plak, calculus) dari permukaan gigi (Putri, Herijulianti, dan Nurjanah, 2016).

\section{Cara penilaian kebersihan gigi dan mulut}

Priyono (dalam Putri, Herijulianti, dan Nurjanah, 2016), ada beberapa cara mengukur atau menilai kebersihan mulut seseorang yaitu Oral Hygiene Index (OHI-S), Oral Hygiene Index Simplified (OHI-S), Personal Hygiene Performance (PHP), Personal Hygiene Performance Modified (PHPM). Penelitian ini menggunakan cara pengukuran kebersihan gigi dan mulut (OHI-S)

a. Oral Hygiene Index Simplified (OHI-S) Green dan Vermillion (dalam Putri, Herijulianti, dan Nurjanah, 2016), index yang digunakan untuk mengukur kebersihan gigi dan mulut disebut Oral Hygiene Index Simplified (OHIS). OHI-S merupakan tingkat kebersihan gigi dan mulut dengan menjum lahkan Debris Index (DI) dan Calculus Index (Cl).Debris Index merupakan nilai (skor) yang diperoleh dari hasil pemeriksaan terhadap endapan lunak dipermukaan gigi yang dapat berupa plak, material alba, dan food debris, sedangkan Calculus Index merupakan nilai (skor) dari endapan keras yang terjadi akibat pengendapan garam-garam anorganik yang komposisi utamanya adalah kalsium karbonat dan kaslium fosfat yang bercampur dengan debris, mikroorganisme, dan sel-sel ephitel deskuamasi dalam (Putri, Herijulianti, dan Nurjanah, 2016).

b. Gigi Indeks OHI-S

Green dan Vermillion (dalam Putri, Herijulianti, dan Nurjanah, 2016) untuk mengukur kebersihan gigi dan mulut seseorang, dipilih enam permukaan gigi index tertentu yang cukup dapat mewakili segment depan maupun belakang dari seluruh permukaan gigi yang ada dalam rongga mulut. Gigi-gigi yang dipilih sebagai gigi index beserta 
permukaan index yang dianggap mewakili tiap segme/st adalah:

1. Gigi 16 pada permukaan bukal

2. Gigi 11 pada permukaan labial

3. Gigi 26 pada permukaan bukal

4. Gigi 36 pada permukaan lingual

5. Gigi 31 pada permukaan labial

6. Gigi 46 pada permukaan lingual.

Kriteria penilaian Menurut Green dan Vermillion (dalam Putri, Herijulianti, dan Nurjanah, 2016), kriteria penilaian Debris Index dan Calculus Index pada pemeriksaan kesehatan gigi dan mulut sama, yaitu dengan mengikuti ketentuan sebagai berikut:

- Baik: Jika nilainya antara 0-0,6

- Sedang: Jika nilainya antara 0,7-1,8

- Buruk: Jika nilalinya antara 1,9-3,0

Skor OHI-S adalah jum lah skor debris index dan skor calculus index sehingga pada perhitungan skor $\mathrm{OHI}-\mathrm{S}$ didapat sebagai berikut:

- Baik: Jika nilainya antara 0-1,2

- Sedang: Jika nilainya antara 1,3-3,0

- Buruk: Jika nilalinya antara 3,1-6,0

\section{Karies Gigi}

Karies gigi adalah penyakit jaringan gigi yang ditandai dengan kerusakan jaringan, dimulai dari permukaan gigi (ceruk, fisura dan daerah interproksimal) meluas ke arah pulpa. Karies gigi dapat dialam i oleh setiap orang dan dapat timbul pada satu permukaan gigi atau lebih, serta dapat meluas ke bagian yang lebih dalam dari gigi, misalnya dari email ke dentin atau ke pulpa (Tarigan, 2016).

Karies gigi merupakan suatu penyakit mengenai jaringan keras gigi, yaitu enamel, dentin dan sementum, berupa daerah yang membusuk pada gigi, terjadi akibat proses secara bertahap melarutkan mineral permukaan gigi dan terus berkembang kebagian dalam gigi. Proses ini terjadi karena aktivitas jasad renik dalam karbohidrat yang dapat diragikan. Proses ini ditandai dengan dimineralisasi jaringan keras dan diikuti kerusakan zat organiknya, sehingga dapat terjadi invasi bakteri lebih jauh ke bagian dalam gigi, yaitu lapisan dentin serta dapat mencapai pulpa (Kumala, 2017).

Karies gigi merupakan penyakit yang disebabkan oleh banyak faktor. Adapun factor utama penyebab karies yaitu host (gigi dansaliva), mikroorganisme (plak), substrat (karbohidrat) dan ditambah faktor waktu (Sondang dan Hamada,2018).

\section{Etiologi karies gigi}

Karies gigi merupakan penyakit periodontal yang dapat menyerang seluruh lapisan.etiologi karies bersifat multifaktorial,sehingga memerlukan faktor-faktor penting seperti: host, agent, mikroorganisme, substrat dan waktu.

a. Faktor Hospes (gigi)

b. Faktor Mikroorganisme

c. Faktor Substrat

d. Faktor Waktu

\section{Karies Pada Anak}

Karies gigi banyak sekali terjadi pada anak-anak karena kebiasaan mengkonsumsi makanan manis yang bisa menyebabkan terjadinya karies gigi. Dampak yang terjadi bila sejak awal sudah mengalami karies adalah selain fungsi gigi sebagai pengunyah yang terganggu, rewel, gusi bengkak, anak juga akan mengalami gangguan dalam menjalankan aktifitasnya seharihari, sehingga anak tidak mau makan dan akibat yang lebih parah bisa terjadi malnutrisi, anak tidak akan dapat belajar karena kurang berkonsentrasi sehingga akan mempengaruhi kecerdasan. Bila anak menderita malnutrisi, hal tersebut akan menyebabkan daya tahan tubuh anak menurun dan anak akan mudah terkena penyakit (Martaputra (2017).

\section{Penilaian status karies}

Indeks Karies Gigi

Herijulianti (2017) menyatakan bahwa

indeks karies gigi adalah angka yang 
menunjukkan Indeks penyakit karies gigi. Indeks karies yang bisa dipakai adalah:

- Untuk gigi tetap : Indeks DMF-T

- Untuk gigi susu : Indeks def-t

Indeks DMF -T (DMF-Teeth)

- $\mathrm{D}=$ Decay: jumlah gigi karies yang masih dapat ditambal

- $\mathrm{M}=$ Missing: jumlah gigi yang telah/harus dicabut karena karies

- $\mathrm{F}=$ Filling: jum ah gigi yang telah ditambal

\section{Indeks def-I (def-teeth)}

- $\quad d=$ Decay: jum lah gigi karies yang masih dapat ditambal

- $\mathrm{e}=$ Eksofoliasi: jum lah gigi susu yang tetah/ harus dicabut karena karies.

- $f=$ Filling: jumlah gigi yang telah ditambal kekurangan indeks def-t

- $\mathrm{E}=$ Eksofoliasi, seharusnya dapat menunjukkan jum lah gigi yang mudah dicabut karena karies.

\section{METODE PENELITIAN}

Jenis penelitian ini bersifat deskriptif dengan membuat uraian secara sistematis mengenai hasil penelitian kemudian distribusikan dalam bentuk tabel. Populasi yang diambil pada penelitian ini adalah semua siswa kelas IV di Sekolah Dasar Negeri Minasa Upa dengan jumlah 605 siswa sedangkan sampel pada penitian ini dengan menggunakan metode proposive sampling DAN diambil berdasarkan kriteria dengan OHIS dan karies tertinggi yakni kelas IV sebanyak 54 responden.

\section{HASIL PENELITIAN}

Telah dilakukan penelitian yang bertujuan untuk mengetahui gambaran kebersihan gigi dan mulut terhadap terjadinya karies pada anak usia Sekolah Dasar Kelas IV Di Minasa Upa. Penelitian dilakukan dengan pemeriksaan gigi dengan menggunakan DMF-T / def-t serta OHI-S yang diperoleh dengan menggunakan pemeriksaan langsung di rongga mulut.

Tabel 1. Distribusi Karakteristik Siswa kelas IV Berdasarkan Jenis Kelamin di SD Negeri Minasa Upa

\begin{tabular}{|c|c|c|}
\hline Jenis Kelamin & Jumlah & Persentase \\
\hline laki-laki & 31 & 57,5 \\
\hline perempuan & 23 & 42,5 \\
\hline Jumlah & $\mathbf{5 4}$ & $\mathbf{1 0 0}$ \\
\hline
\end{tabular}

Berdasarkan tabel 1 dapat diketahui bahwa sebanyak 31 siswa (42,5\%). Sisanya berjenis mayoritas responden berjenis kelamin laki-laki kelamin perempuan sebanyak 23 siswa $(57,5 \%)$.

Tabel 2. Distribusi Status Kebersihan Gigi dan mulut (OHI-S) pada siswa kelas IV di SD Negeri Minasa Upa

\begin{tabular}{|c|c|c|}
\hline OHI-S & JUMLAH & PERSENTASE \\
\hline Baik & 19 & 35,18 \\
\hline Sedang & 35 & 61,12 \\
\hline Buruk & 0 & 0 \\
\hline Total & $\mathbf{5 4}$ & $\mathbf{1 0 0}$ \\
\hline
\end{tabular}

Berdasarkan Tabel 2. dapat dilihat bahwa status kebersihan gigi dan mulut pada Siswa kelas IVdi SD Negeri Minasa Upa Kel.
Minasa Upa Kec. Rappocini yaitu Kategori Baik (35,18\%), Kategori Sedang $(61,12 \%)$, dan Kategori Buruk (0\%). 
Tabel 3. Distribusi Kebersihan Gigi dan Mulut Terhadap Status Karies(def-t) pada Anak Usia Sekolah Dasar di SD Negeri Minasa Upa

\begin{tabular}{|c|c|c|c|c|c|c|c|}
\hline \multirow{2}{*}{ OHI-S } & \multirow{2}{*}{ Jumlah } & \multicolumn{4}{|c|}{ Status Karies } & \multirow{2}{*}{ Rata -rata } & \multirow{2}{*}{ Kategori } \\
\hline & & $d$ & $e$ & $f$ & def-t & & \\
\hline Baik & 19 & 17 & 4 & 0 & 21 & 0,2 & $\begin{array}{l}\text { Sangat } \\
\text { rendah }\end{array}$ \\
\hline Sedang & 35 & 39 & 0 & 0 & 39 & 0,5 & $\begin{array}{l}\text { Sangat } \\
\text { rendah }\end{array}$ \\
\hline Buruk & 0 & 0 & 0 & 0 & 0 & 0 & $\begin{array}{l}\text { Sangat } \\
\text { rendah }\end{array}$ \\
\hline Jumlah & 54 & 40 & 4 & 0 & 44 & 0,23 & $\begin{array}{l}\text { Sangat } \\
\text { rendah }\end{array}$ \\
\hline
\end{tabular}

Berdasarkan tabel 3 diatas dapat diketahui bahwa kebersihan gigi dan mulut $(\mathrm{OHI}-$
S) sedang 35 orang anak dengan def-t 35 dan nilai rata-rata 0,5 termasuk kategori sedang.

Tabel 4. Distribusi Kebersihan Gigi dan Mulut Terhadap Status Karies(DMF-T) pada Anak Usia Sekolah Dasar di SD Negeri Minasa Upa

\begin{tabular}{|c|c|c|c|c|c|c|c|}
\hline \multicolumn{8}{|c|}{ asar al suegeni ininasa } \\
\hline \multirow{2}{*}{ OHI-S } & \multirow{2}{*}{ Jumlah } & \multicolumn{4}{|c|}{ Status Karies } & \multirow{2}{*}{ Rata -rata } & \multirow{2}{*}{ Kategori } \\
\hline & & $D$ & $M$ & $F$ & DMF-T & & \\
\hline Baik & 19 & 4 & 0 & 0 & 4 & 0,7 & $\begin{array}{l}\text { Sangat } \\
\text { rendah }\end{array}$ \\
\hline Sedang & 35 & 198 & 0 & 0 & 198 & 3,6 & sedang \\
\hline Buruk & 0 & 0 & 0 & 0 & 0 & 0 & $\begin{array}{l}\text { Sangat } \\
\text { rendah }\end{array}$ \\
\hline Jumlah & 54 & 202 & 0 & 0 & 202 & 1,9 & rendah \\
\hline
\end{tabular}

Berdasarkan tabel 4 di atas dapat diketahui bahwa kebersihan gigi dan mulut sedang 35

\section{PEMBAHASAN}

Penelitian ini menunjukkan bahwa jumlah responden yang paling banyak adalah laki-laki dibandingkan dengan responden perempuan. Berdasarkan dari hasil pemeriksaan status kebersihan gigi dan mulut $(\mathrm{OHI}-\mathrm{S})$ dari 54 responden didapatkan hasil bahwa status kebersihan gigi dan mulut berada pada kategori sedang, yakni 35 responden (61,12\%). Hal ini dikarenakan perilaku anak yang sering menggosok gigi sebelum tidur.

Hal tersebut dilakukan juga karena dorongan dan motivasi dari orang tua dirumah yang selalu memberikan edukasi mengenai kesehatan gigi dan mulut. Pengetahuan orang tua dalam hal ini sangat membantu dalam pemeliharaan gigi dan mulut anak. orang anak dengan DMF-T 198 dan nilai rata-rata 3,6 termasuk kategori sedang.

Selain dari kebersihan gigi daan mulut yang tidak buruk, didapatkan pula hasil bahwa status karies anak def-t menunjukkan hasil yang sangat rendah. Kondisi ini dikarenakan enggosok gigi sebelum tidur sangat berpengaruh terhadp perkembangan bakteri yang mampu dihambat ketika anaak tertidur dimalam hari. Begitupun dengan status karies DMF-T yang didapatkan hasil dengan kategori rendah dengan rata-rata $1,9 \%$ dari 54 responden.

$\mathrm{Hal}$ ini sejalan yang dengan penelitian di Kuwait di kutip oleh Maureen (2015) dengan hasil penelitian pada anak usia 5-14 tahun, sebanyak $3,9 \%$ memiliki kategori baik, 67\% kategori sedang, dan $29 \%$ dalam kategori buruk dan nilai OHI-S rata-rata yaitu 1,5 merupakan kategori sedang. 


\section{KESIMPULAN}

1. Status kebersihan gigi dan mulut $(\mathrm{OHI}-\mathrm{S})$ pada siswa kelas IV SD Negeri Minasa Upa Kel. Minasa Upa Kec. Rappocini termasuk dalam kategori sedang.

2. Terdapat adanya karies pada siswa kelas IV SD Negeri Minasa Upa Kel. Minasa Upa Kec. Rappocini untuk def-t sangat rendah dan DMF-T sedang.

\section{SARAN}

Berdasarkan penelitian yang telah dilakukan maka dapat diajukan saran sebagai berikut:

1. Perlunya peran orang tua dalam mengarahkan anak untuk mengutamakan kesadaran pentingnya menjaga kesehatan gigi dan mulut, dan diarahkan untuk melakukan pemeriksaan kedokter gigi setiap 6 bulan sekali agar mencegah penyakit gigi dan mulut.

2. Perlunya lebih ditingkatkan lagi kegiatan promotive berupa penyuluhan kesehatan gigi disertai alat peraga yang sesui dengan materi penyuluhan untuk meningkatkan pengetahuan siswa tentang kesehatan gigi dan mulut.

3. Perlunya peningkatan pemeriksaan gigi dan mulut pada siswa untuk melihat prevalensi penyakit gigi pada masa berikutnya.

\section{DAFTAR PUSTAKA}

Be, 2017: Hubungan Teknik Menggosok Gigi dan Kebersihan Gigi dan Mulut (Oral Hygiene Indeks Simplified) 2017. Dentino Jurnal Kedoteran Gigi
Be, 2017: Pengertian Karies Gigi.Yogyakarta : Gadjah Mada University Pres.

Depkes RI, 2016: Defenisi Upaya Kesehatan Gigi dan Mulut Anak http://www.mitrasehat.com/diakses tanggal 30 juni 2015

Depkes RI,2017: IImu Kedokteran Gigi Pencegahan Karies, Yogyakarta Gadjah Mada University Press

Dinkes, 2017: upaya kesehatan gigi dan mulut anak terhadap karies http://www.mitrasehat.com/diakses 30 juni 2017.

Farida, 2015, pengertian kebersihan gigi dan mulut, jurnal 2015.

G.V.Black, 2016, klarifikasi karies gigi, buku konservasi gigi,2016.

Kumala, 2017, Pengertian Karies Gigi,Jurnal Kesehatan 2017

Martaputra, 2017, Akibat Karies Pada Anak Usia Sekolah Dasar Terhadap Makanan Kariogenik,Jurnal Kesehatan 2017.

Putri,Herijulanti Dan Nurjannah, 2016: Faktor Yang Mempengaruhi Kebersihan Gigi Dan Mulut,Jurnal kesehatan 2016.

Priyono, 2016, Gambaran OHI-S Dan Perilaku Menyikat Gigi Pada siswa Kelas IV Di SDN 5 Pekutatan Kecamatan Pekutatan Kabupaten Jembrana Tahun 2016, jurnal Skala Husada 2016.

Priyono, 2016: Bascis Guide to Oral Health Education and Promotion.KHL Printing Malaysia.

Rusmawati, 2017: Hubungan Indeks Kebersihan Gigi DanMulut Dengan Indeks Karies Gigi Pada Murid SDN 03 Pakan Kurai Kecamatan Guguk Panjang Kota Bukit Tinggi.Jurnal Kesehatan Gigi

Sari Ningsih, 2107: Hubungan Teknik Menggosok Gigi Dan Kebersihan Gigi Dan Mulut (Oral Hygiene Indeks Simplified). 2017

World health organization ,2016, karies gigi ,Jurnal Kesehatan2016.

Yanti, 2016, Akibat Tidak Memelihara Kebersihan Gigi Dan Mulut, Jurnal Kesehatan 2016. 